\title{
Kromatografska analiza u sustavu kvalitete analitičkoga procesa u Zavodu za analitičku kemiju Fakulteta kemijskog inženjerstva i tehnologije
}

D. Ašperger, S. Babić, T. Bolanča, D. Mutavdžić Pavlović i Š. Ukić

Zavod za analitičku kemiju, Fakultet kemijskog inženjerstva i tehnologije Sveučilišta u Zagrebu,

Marulićev trg 19, 10000 Zagreb

\begin{abstract}
Sažetak đenjem nastavnog programa $\mathrm{i}$ istraživačkog rada.

Ključne riječi

Kromatografija, analitička kemija, sustav kvalitete, okoliš
\end{abstract}

Bez analitičke kemije nemoguće je zamisliti napredak mnogih područja ljudske djelatnosti. Spomenuti značaj ove grane kemije jedan je od glavnih razloga uspješnog opstanka i kontinuiranog razvoja Zavoda za analitičku kemiju unutar jednog tehničkog fakulteta, kao što je današnji Fakultet kemijskog inženjerstva i tehnologije (FKIT) Sveučilišta u Zagrebu. Dinamičnost razvoja analitičke kemije bila je neprestani poticaj nastavnicima Zavoda za prilagođavanjem svjetskim trendovima i sustavnim unaprje-

Početak nastavnog, znanstvenog, ali i stručnog djelovanja Zavoda temeljio se na klasičnim metodama analize, no potaknuta razvojem moderne analitičke opreme ubrzo se intenzivirala primjena brojnih kemijskih i fizikalno-kemijskih metoda analize, od kojih je danas najzastupljenija kromatografija. Naime, konac dvadesetog stoljeća ubrzanim je razvojem instrumentalnih tehnika, uvođenjem računala i činjenicom da su podatci analitičkih mjerenja postali temelj odlučivanja u medicini, zaštiti okoliša, razvoju materijala te osiguravanju kvalitete procesa i proizvoda, dao novi uzlet analitičkoj kemiji, a osobit procvat doživjela je kromatografija kao idealna tehnika za višekomponentnu analizu analita u tragovima.

\section{Ukratko o kromatografiji1-5}

Drži se da je otac ruski botaničar rođen u Italiji M. S. Cvet (1872. - 1919.), dok su teorijsku pozadinu moderne tekućinske kromatografije prvi objasnili dvojica britanskih kemičara i dobitnika Nobelove nagrade 1952. A. J. P. Martin (1910. - 2002.) i R. L. M. Synge (1914. - 1994.). Prema IUPAC-ovoj definiciji, pod pojmom kromatografije smatraju se i tehnike odvajanja električnom strujom, tj. elektroforetske tehnike. Na tom području dodijeljena je Nobelova nagrada 1948. švedskom kemičaru A. W. K. Tiseliusu (1902. - 1971.). Kromatografija podrazumijeva širok raspon metoda koje se primjenjuju za odjeljivanje i analizu složenih smjesa spojeva, pa je danas jedna od najučinkovitijih separacijskih tehnika što je čini primjenjivom za rješavanje brojnih analitičkih problema. Primjenjuje se za simultano odjeljivanje, identifikaciju i kvantifikaciju vrlo različitih spojeva i skupina spojeva u više ili manje složenim maticama. Kromatografske tehnike primjenjuju se u različitim područjima ljudskoga djelovanja, a danas je njezina najveća primjena u analizi okoliša (voda, tlo, sediment, zrak).

Kromatografski sustav čine nepokretna i pokretna faza te ispitivani spoj. Prilikom kromatografske analize smjesa različitih sastojaka uzorka ulazi u kromatografski stupac ili na kromatografsku plohu, pri čemu se sastojci uzorka razdjeljuju između pokretne i nepokretne faze s ciljem postizanja ravnoteže. Pojedini sastojci uzorka imaju različite afinite-

*Autor za dopisivanje: prof. dr. sc. Danijela Ašperger,

e-pošta: diva@fkit.hr te prema pokretnoj i nepokretnoj fazi. Budući da putuju samo kada se nalaze u pokretnoj fazi, dolazi do različitih relativnih brzina putovanja kroz kolonu, ovisno o afinitetu prema pokretnoj, odnosno nepokretnoj fazi. Upravo razlika u relativnim brzinama putovanja omogućuje veliku selektivnost te tehnike. Stoga izbor faza treba biti takav da zadržavanje molekula u sustavu bude što selektivnije; na njega utječu priroda ispitivanog spoja, priroda ravnoteže $u$ sustavu te veza između ispitivanog spoja i nepokretne faze.

Danas se važnost te analitičke tehnike očituje na svakom koraku. U bilo kojem kemijskom, biokemijskom, geokemijskom, farmaceutskom i drugom prirodoslovnom laboratoriju nerijetko postoje hitni zahtjevi za razdvajanjem složenih smjesa te kvalitativnom identifikacijom, a u većini slučajeva i kvantifikacijom njihovih sastojaka. Slično tome, izoliranje i pročišćavanje proizvoda nužan je i važan korak u mnogim industrijskim proizvodnim linijama.

\section{Razvojni put kromatografije u Zavodu za analitičku kemiju ${ }^{6,7}$}

Zavod za analitičku kemiju današnjeg Fakulteta kemijskog inženjerstva i tehnologije utemeljen je kao samostalna znanstveno-nastavna jedinica Tehničke visoke škole u Zagrebu 18. prosinca 1919., čime je postao i prvi visokoškolski Zavod za analitičku kemiju u Hrvatskoj. Treba napomenuti da se analitička kemija i prije toga predavala i znanstveno razvijala na Mudroslovnom fakultetu Sveučilišta u Zagrebu i Agrikulturno-kemijskom zavodu u Križev- 
cima, međutim od navedenog datuma prvi put zasebno i samostalno u Zavodu za analitičku kemiju Tehničke visoke škole u Zagrebu.

Zavod za analitičku kemiju danas se nalazi u prizemlju zgrade na Marulićevom trgu 20 i sastoji se od tri studentska laboratorija: Laboratorija za mokru analizu, Laboratorija za kvalitativnu i klasičnu kvantitativnu analizu te Instrumentalnog laboratorija. Uz navedene laboratorije sastavni dio Zavoda su i Centar za kromatografiju te Laboratorij za analizu okoliša. Zavod ima osnovnu opremu za izvođenje vježbi iz klasične analitičke kemije kao i nužne instrumente za obavljanje vježbi iz područja instrumentalne i procesne analize, koji se ujedno upotrebljavaju i za znanstveni i stručni rad.

Temeljna zadaća Zavoda za analitičku kemiju bila je i ostala školovati stručnjake za potrebe kemijske industrije ne zanemarujući ulogu znanstvenih istraživanja. Stoga svi kolegiji koji su se predavali ili se i dalje predaju na ovome Zavodu neizostavno u svojoj izvedbi imaju uključene i laboratorijske vježbe. S osnovama kromatografskih tehnika studenti se tijekom studija susreću u više kolegija, a dodatne vještine usvajaju izradom završnih i diplomskih radova. Kao neminovni nastavak, na Zavodu je obranjen niz disertacija s kromatografskom tematikom.

Kromatografske tehnike se na Zavodu uvode prvi put u nastavu u akademskoj godini 1951./52. kada započinju predavanja iz kolegija Specijalne metode kemijske analize kao izbornog kolegija u VIII. semestru studija. U tom su kolegiju obrađivane tada moderne analitičke tehnike poput kromatografije te fizikalno-kemijski fenomeni poput ionske izmjene $\mathrm{i}$ ekstrakcije. Radi osuvremenjivanja nastavnog programa 1971. uvodi se kolegij Instrumentalna analiza u VII. semestru studija. Bio je to obvezatni kolegij za sve smjerove, a u njemu su se osim ostalog tumačile i teorijske osnove kromatografskih tehnika. Nastavnici Zavoda sudjelovali su i u izvođenju nastave na poslijediplomskim studijima, počevši već od studija Kemija i tehnologija silikata pokrenutog u sklopu tadašnjeg Tehnološkog fakulteta. Već prvih godina djelovanja tog studija, konkretnije od akademske godine 1963./64., izvodi se kolegij Analiza silikatnih materijala, a nešto kasnije i Kromatografija I.

Uvrštavanje aktualnih analitičkih trendova u izvedbene programe kolegija nastavljeno je do današnjih dana. Početkom 1990.-ih godina dolazi do naglog razvoja ionske kromatografije kao analitičke tehnike predodređene za analizu anorganskog sastava voda, čija se selektivnost temeljila na procesima ionske izmjene. Kao posljedica toga, na poslijediplomskom studiju FKIT-a pokreće se kolegij lonska kromatografija, a nedugo potom, uvidjevši neadekvatnu povezanost znanosti i struke, članovi Zavoda (na čelu s prof. Šteficom Cerjan Stefanović) pokreću i niz godišnjih okupljanja kromatografičara iz Hrvatske, ali i iz susjednih država te iz država širom Europe. $U$ početku su se ti skupovi nazivali Međunarodna škola ionske kromatografije, a s vremenom, uvidjevši nepotrebno ograničavanje na samo jednu kromatografsku tehniku, promijenili su ime u Međunarodna škola kromatografije, te se kao takvi, uz zavidnu posjećenost, održavaju i danas. Iznimno velika zastupljenost kromatografije u mnogobrojnim znanstvenim i stručnim djelatnostima dovela je do toga da su članovi Zavoda, mimo regularnih nastavnih aktivnosti namijenjenih studentima FKIT-a, tijekom proteklih 15-ak godina održavali i čitav niz kromatografskih edukacija namijenjenih onima koji se tijekom dotadašnje izobrazbe nisu u dovoljnoj mjeri susreli s kromatografskim tehnikama.

Jedna od stalnih potreba u kemijskoj analizi jest svođenje pogreške na najmanju mjeru. Razvoj modernih računala omogućio je brzu primjenu statističkih metoda, čime je pouzdanje $u$ analitički rezultat (primarno temeljeno na pouzdanju u rad analitičara) postupno zamijenjeno statističkom vjerojatnošću rezultata. Uz to, moderne analitičke tehnike generiraju sve veći broj podataka, a u takvim situacijama pronalazak uzroka ponašanja nerijetko je moguć samo intenzivnom matematičkom obradbom. Upravo stoga se članovi Zavoda počinju baviti i Kemometrijom, tehnikom fokusiranom na sveopću primjenu matematike u kemiji. Uvođenje Kemometrije kao nastavne teme podudara se s prelaskom studiranja na bolonjski sustav, kada je studij osvježen velikim brojem novih kolegija. Uz izvođenje na doktorskom studiju FKIT-a, Kemometrija od akademske godine 2009./10. postaje i jedan od obvezatnih kolegija na diplomskom studiju Primijenjena kemija, a neizravno se počinje obrađivati i u drugim kolegijima. Unutar Kemometrije dolazi i do sve veće fokusiranosti na ispitivanje kvalitete i procjenu rizika koje također zahtijeva intenzivnu primjenu matematike s osobitim naglaskom na teoriju vjerojatnosti; važnost tog područja vidi se i u uvođenju kolegija Ispitivanje kvalitete i Upravljanje kvalitetom, koji se održavaju od akademske godine 1996./97., odnosno 2005./06. kada postaju obvezatni predmeti na diplomskom studiju.

Znanstveni radovi nastavnika Zavoda za analitičku kemiju objavljeni u dvije monografije ${ }^{1,2}$ ukazuju da je prvi znanstveni rad iz područja kromatografije objavila profesorica Vjera Marjanović u koautorstvu sa Srećkom Turinom pod naslovom "Dokazivanje i određivanje nekih elemenata iz tekuće i plinovite faze metodom kromatografije direktne indikacije na kolonama" u časopisu Kemija u industriji, 10, 159-162, daleke 1961. godine. Razvoj kromatografskih tehnika putem znanosti i nastave rezultirao je nizom znanstvenih radova. Ovdje navodimo samo radove svih nastavnika Zavoda za analitičku kemiju u proteklih deset godina, odnosno od 2009. do 2019., budući da su ostali radovi navedeni u prethodno spomenutim monografijama. Popis ukazuje na široku primjenu kromatografskih tehnika s interdisciplinarnim pristupom, ali također i nastavak tradicije u praćenju najsuvremenijih svjetskih trendova te da Zavod za analitičku kemiju ne zaostaje za međunarodnom scenom na tom području. Međutim, znanstveni rad je pretočen i u nastavu s ciljem osuvremenjivanja nastavnog sadržaja, što je rezultiralo time da su u posljednjih deset godina objavljena dva sveučilišna udžbenika (slika 1), 12 poglavlja u sedam knjiga i 107 radova citiranih u bazi Current Contents: ${ }^{8}$ 

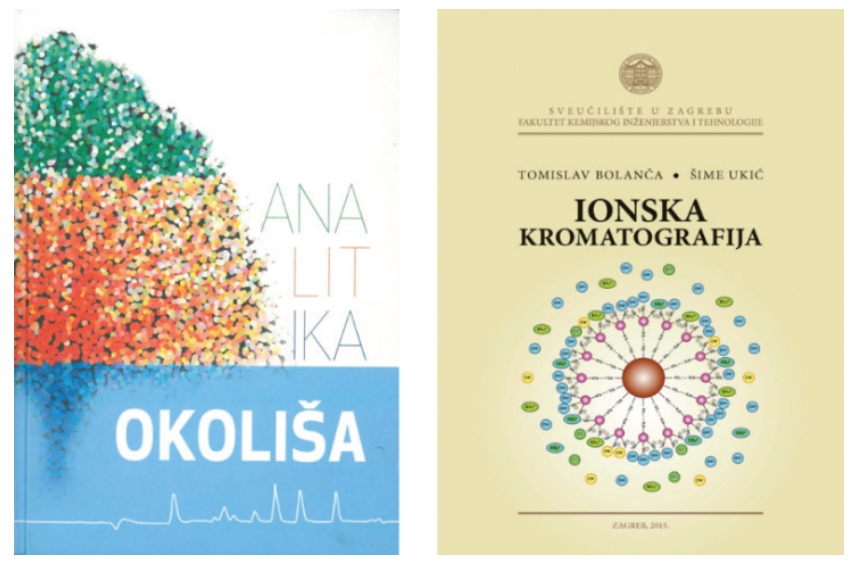

Slika 1 - Sveučilišni udžbenici nastavnika Zavoda za analitičku kemiju objavljeni 2013. (Kemija okoliša) i 2015. (lonska kromatografija)

Fig. 1 - University Textbooks of the teachers of the Department of Analytical Chemistry published in 2013 (Kemija okoliša) and 2015 (Ionska kromatografija)

\subsection{Sveučilišni udžbenici}

1. T. Bolanča, Š. Ukić: Ionska kromatografija, Fakultet kemijskog inženjerstva i tehnologije, Zagreb, 2015.

2. M. Kaštelan-Macan, M. Petrović, D. Ašperger, S. Babić, T. Bolanča, R. M. Dabra, S. Ferina, A. Ginebreda, A. J. M. Horvat, G. Klobučar, J. Macan, D. Mutavdžić Pavlović, R. Sauerborn Klobučar, A. Štambuk, V. Tomašić, Š. Ukić, Analitika okoliša (ur. Marija Kaštelan-Macan, Mira Petrović), HINUS i Fakultet kemijskog inženjerstva i tehnologije, Zagreb, 2013.

\subsection{Poglavlja u knjizi}

1. T. Bolanča, Š. Ukić, M. Novak Stankov, Environmental Chemistry in: Environmental Engineering: Basic Principles (ur. V. Tomašić i B. Zelić), Berlin/Boston: Walter de Gruyter $\mathrm{GmbH}$, 2018., str. 47-84.

1. D. Ašperger, D. Dolar, K. Košutić, H. Kušić, A. Lončarić Božić, M. Vuković Domanovac, Water and wastewater treatment engineering in: Environmental Engineering: Basic Principles (ur. V. Tomašić i B. Zelić), Berlin/Boston: Walter de Gruyter $\mathrm{GmbH}, 2018$., str. 241-276.

2. P. Verlicchi, D. Barceló, D. Mutavdžić Pavlović, M. Papa, M. Petrović, N. Voulvolis, E. Zambello, Chapter 24: The impact and risks of micropollutants in the environment in: Innovative Wastewater Treatment \& Resource Recovery Technologies: Impacts on Energy, Economy and Environment (ur. J. M. Lema, S. Suarez), IWA Publishing, 2017., str. 510-533.

3. I. Tomaz, P. Štambuk, Ž. Andabaka, D. Preiner, D. Stupić, E. Maletić, J. Karoglan Kontić, D. Ašperger, The Polyphenolic Profile of Grapes in: Grapes: Polyphenolic Composition, Antioxidant Characteristics and Health Benefits (ur. Sandra Thomas), New York: Nova Science Publishers, Inc., 2017. str. 1-70.

4. S. Babić, D. Mutavdžić Pavlović, Analysis of PhACs in solid environmental samples (soil, sediment, sludge) in: Analysis, Removal, Effects and Risk of Pharmaceuticals in the Water Cycle: Occurrence and Transformation in the Environment (ur. M. Petrovic, S. Perez i D. Barcelo), Elsevier, 2013., str. 129-169.

5. S. Babić, D. Ašperger, Uzorkovanje u: Analitika okoliša (ur.
M. Kaštelan-Macan i M. Petrović), HINUS i Fakultet kemijskog inženjerstva i tehnologije Sveučilišta u Zagrebu, Zagreb 2013., str. 115-139.

6. D. Mutavdžić Pavlović, D. Ašperger, Priprava uzorka u: Analitika okoliša (ur. M. Kaštelan-Macan i M. Petrović), HINUS i Fakultet kemijskog inženjerstva i tehnologije Sveučilišta u Zagrebu, Zagreb 2013., str. 140-171.

7. M. Petrović, D. Mutavdžić Pavlović, S. Babić, A. J. M. Horvat, $D$. Ašperger, Analiza tragova i ultratragova u: Analitika okoliša (ur. M. Kaštelan-Macan i M. Petrović), HINUS i Fakultet kemijskog inženjerstva i tehnologije Sveučilišta u Zagrebu, Zagreb 2013., str. 250-304.

8. S. Babić, Osiguravanje kvalitete mjernih podataka u: Analitika okoliša (ur. M. Kaštelan-Macan i M. Petrović), HINUS i Fakultet kemijskog inženjerstva i tehnologije Sveučilišta u Zagrebu, Zagreb 2013., str. 339-358.

9. T. Bolanča, Š. Ukić, Kemometrika u analitici okoliša u: Analitika okoliša (ur. M. Kaštelan-Macan i M. Petrović), HINUS i Fakultet kemijskog inženjerstva i tehnologije Sveučilišta u Zagrebu, Zagreb 2013., str. 359-373.

10. M. Petrović, S. Babić, A. Ginebreda, R. M. Darbra, Procjena Rizika u: Analitika okoliša (ur. M. Kaštelan-Macan i M. Petrović), HINUS i Fakultet kemijskog inženjerstva i tehnologije Sveučilišta u Zagrebu, Zagreb 2013., str. 375-396.

11. K. Margeta, D. Mutavdžić Pavlović, D. Ašperger, Š. Ukić, Analitička kemija u okolišu u: Zaštita okoliša i regionalni razvoj - iskustva i perspektive (ur. S. Tišma, S. Maleković), Institut za međunarodne odnose, Zagreb, 2009., str. 243-265.

\subsection{Izvorni znanstveni i pregledni radovi u CC časopisima}

\section{9.:}

1. D. Dabić, S. Babić, I. Škorić, The role of photodegradation in the environmental fate of hydroxychloroquine, Chemosphere 230 (2019) 268-277.

2. K. Tolić, D. Mutavdžić Pavlović, D. Židanić, M. Runje, Nitrofurantoin in sediments and soils: Sorption, isotherms and kinetics, Sci. Total Environ. 681 (2019) 9-17.

3. M. Cvetnić, D. Juretić Perišić, M. Kovačić, Š. Ukić, T. Bolanča, B. Rasulev, H. Kušić, A. Lončarić Božić, Toxicity of aromatic pollutants and photooxidative intermediates in water: A QSAR study, Ecotox. Environ. Safe. 169 (2019) 918-927.

4. D. Mutavdžić Pavlović, T. Gazivoda Kraljević, R. Pavić, J. Mrđa, Determination of anthelmintic pharmaceuticals in wastewater by SPE and TLC, JPC-J. Planar Chromat. 32 (2019) 421-429.

5. M. Cvetnić, M. Novak Stankov, M. Kovačić, Š. Ukić, T. Bolanča, B. Rasulev, D. Dionysiou, A. Lončarić Božić, Key structural features promoting radical driven degradation of emerging contaminants in water, Environ. Int. 124 (2019) 38-48.

6. M. Čizmić, D. Ljubas, M.Rožman, D. Ašperger, L. Ćurković, S. Babić, Photocatalytic Degradation of Azithromycin by Nanostructured $\mathrm{TiO}_{2}$ Film: Kinetics, Degradation Products, and Toxicity, Materials 12 (6) (2019) 873-889.

7. D. Kučić Grgić, V. Ocelić Bulatović, M. Cvetnić, Ž. Dujmić Vučinić, M. Vuković Domanovac, M. Markić, T. Bolanča, Biodegradation kinetics of diuron by Pseudomonas aeruginosa FN and optimization of biodegradation using response surface methodology, Water Environ. J. 1 (2019) 1-13.

8. R. Pedrazzani, G. Bertanza, I. Brnardić, Z. Cetecioglu, J. Dries, J. Dvarioniene, A. J. García-Fernández, A. Langenhoff, G. Libralato, G. Lofrano, B. Škrbić, E. Martínez- López, S. Meriç, D. 
Mutavdžić Pavlović, M. Papa, P. Schröder, K. P. Tsagarakis, C. Vogelsang, Opinion paper about organic trace pollutants in wastewater: Toxicity assessment in a European perspective, Sci. Total Environ. 651 (2019) 3202-3221.

9. D. Kučić Grgić, M. Vuković Domanovac, T. Domanovac, M. Šabić, M. Cvetnić, V. Ocelić Bulatović, Influence of Bacillus subtilis and Pseudomonas aeruginosa BSW and Clinoptilolite addition of the biowaste composting process, Arab. J. Sci. Eng. 1 (2019) 1-11.

10. I. Tomaz, I. Šikuten, D. Preiner, Ž. Andabaka, N. Huzanić, M. Lesković, J. Karoglan Kontić, D. Ašperger, Stability of polyphenolic extracts from red grape skins after thermal treatments, Chem. Pap. 73 (2019) 195-203.

\section{8.:}

11. S. Babić, M. Biošić, I. Škorić, Transformation Products of Pharmaceuticals in the Environment: Formation and Analysis, Curr. Org. Chem. 22 (2018) 987-1004.

12. D. Mutavdžić Pavlović, A. Glavač, M. Gluhak, M. Runje, Sorption of albendazole in sediments and soils: Isotherms and kinetics, Chemosphere 193 (2018) 635-644.

13. A. Beneta, D. Mutavdžić Pavlović, I. Periša, M. Petrović, Multiresidue GC-MS/MS pesticide analysis for evaluation of tea and herbal infusion safety, Int. J. Environ. Anal. Chem. 98 (2018) 987-1004.

14. S. Babić, D. Mutavdžić Pavlović, M. Biošić, D. Ašperger, I. Škorić, M. Runje, Fate of febantel in the aquatic environment - the role of abiotic elimination processes, Environ. Sci. Pollut. Res. 25 (2018) 28917-28927.

15. M. Čizmić, D. Ljubas, I. Škorić, M. Rožman, D. Ašperger, L. Ćurković, M. Petrović, S. Babić, Photolytic and photocatalytic degradation of febantel in aqueous media, Desalin. Water Treat. 104 (2018) 294-303.

16. Ž. Ujević Andrijić, M. Cvetnić, N. Bolf, Soft Sensor Models for a Fractionation Reformate Plant using Small and Bootstrapped Data Set, Braz. J. Chem. Eng. 35 (2018) 745-756.

17. L. Ćurković, D. Ašperger, S. Babić, J. Župan, Adsorption of enrofloxacin onto natural zeolite: Kinetics, thermodynamics, isotherms and error analysis, Indian J. Chem. Technol. 25(2018) 565-571.

18. D. Lubas, M. Čizmić, K. Vrbat, D. Stipaničev, S. Repec, L. Ćurković, S. Babić, Albendazole Degradation Possibilities by UV-Based Advanced Oxidation Processes, Int. J. Photoenergy 2018 (2018) 1-6.

19. T. Tomić, S. Babić, M. Biošić, N. Uzorinac Nasipak, A.-M. Čižmek, Determination of the Solvent Blue 35 dye in diesel fuel by solid phase extraction and high-performance liquid chromatography with ultraviolet detection, Dyes Pigments 150 (2018) 216-222.

20. M. Đokić, N. Bilandžić, M. Sedak, M. Đuras, T. Gomerčić, M. Benić, T. Bolanča, Manganese concentrations in tissues and skin of three dolphin species stranded in the Croatian waters of the Adriatic Sea from 1995 to 2013, B. Environ. Contam. Tox. 100 (2018) 317-323.

21. M. Markić, M. Cvetnić, ک̌. Ukić, H. Kušić, T. Bolanča, A. Lončarić Božić, Influence of process parameters on the effectiveness of photooxidative treatment of pharmaceuticals, J. Environ. Sci. Health A Tox. Hazard. Subst. Environ. 53 (2018) 338-351.

22. V. Stankov, M. Cvetnić, M. Novak Stankov, M. Rogošić, T. Bolanča, Š. Ukić, Retention Modeling of Gradient Elutions: Application of Iso-to-Grad Approach for LC Systems with Dual-Species Eluent, Chromatographia 82 (2018) 749-755.
2017.:

23. M. Cvetnić, D. Juretić Perišić, M. Kovačić, H. Kušić, J. Đermadi, S. Horvat, T. Bolanča, V. Marin, P. Karamanis, A. Lončarić Božić, Prediction of biodegradability of aromatics in water using QSAR modeling, Ecotoxicol. Environ. Saf. 139 (2017) 139-149.

24. M. Biošić, M. Mitrevski, S. Babić, Environmental behaviour of sulfadiazine, sulfamethazine and their metabolites, Environ. Sci. Pollut. Res. Int. 24 (2017) 9802-9812.

25. D. Mutavdžić Pavlović, L. Ćurković, J. Macan, K. Žižek, Eggshell as a new biosorbent for the removal of the pharmaceuticals from aqueous solutions, Clean : Soil, Air, Water $\mathbf{4 5}$ (2017) 1700082-1-1700082-14.

26. M. Biošić, I. Škorić, J. Beganović, S. Babić, Nitrofurantoin hydrolytic degradation in the environment, Chemosphere 186 (2017) 660-668.

27. I. Brnardić, L. Ćurković, T. Sofilić, D. Mutavdžić Pavlović, G. Matijašić, I. Grčić, A. Rađenović, Removal of Heavy Metals and Pharmaceuticals From Contaminated Water Using Waste Sludge - Kinetics and Mechanisms, Clean : Soil, Air, Water 45 (2017) 1600509-1-1600509-9.

28. M. Čizmić, S. Babić, M. Kaštelan-Macan, Multi-class determination of pharmaceuticals in waste waters by solid phase extraction and liquid chromatography tandem mass spectrometry with matrix effect study, Environ. Sci. Pollut. Res. Int. 24 (2017) 20521-20539.

29. D. Mutavdžić Pavlović, L. Ćurković, I. Grčić, I. Šimić, J. Župan, Isotherm, kinetic and thermodynamic study of ciprofloxacin sorption on sediments, Environ. Sci. Pollut. Res. Int. 24 (2017) 10091-10106.

30. T. Bolanča, T. Strahovnik, Š. Ukić, M. Novak Stankov, M. Rogošić, Modeling of policies for reduction of GHG emissions in energy sector using ANN: case study - Croatia (EU), Environ. Sci. Pollut. Res. Int. 24 (2017) 16172-16185.

31. D. Dolar, N. Drašinac, K. Košutić, I. Škorić, D. Ašperger, Adsorption of hydrophilic and hydrophobic pharmaceuticals on RO/NF membranes: Identification of interactions using FTIR, J. Appl. Polym. Sci. 134 (2017) 44426-1-44426-12.

32. D. Tušek, D. Ašperger, I. Bačić, L. Ćurković, J. Macan, Environmentally acceptable sorbents of chemical warfare agent simulants, J. Mater. Sci. 52 (2017) 2591-2604.

33. M. Cvetnić, Š. Ukić, H. Kušić, T. Bolanča, A. Lončarić Božić, Photooxidative Degradation of Pesticides in Water: Response Surface Modeling Approach, Journal of AOTs, J. Adv. Oxid. Technol. 20 (2017) 14.

34. I. Grčić, I. Brnardić, D. Mutavdžić Pavlović, V. Mandić, S. Papić, Photocatalytic activity of synthesized titanate nanotubes and nanoribbons vs. Commercial $\mathrm{TiO}_{2}$ under artificial solar and visible irradiation using $17 \beta$-estradiol as model micropollutant, Desalin. Water Treat. 67 (2017) 300-308.

35. M. Čizmić, D. Ljubas, L. Ćurković, I. Škorić, S. Babić, Kinetics and degradation pathways of photolytic and photocatalytic oxidation of the anthelmintic drug praziquantel, J. Hazard. Mater. 323 (2017) 500-512.

\section{6.:}

36. M. Pelajić, G. Peček, D. Mutavdžić Pavlović, D. Vitali Čepo, Novel multiresidue method for determination of pesticides in red wine using gas chromatography-mass spectrometry and solid phase extraction, Food Chem. 200 (2016) 98-106.

37. D. Drljača, D. Ašperger, M. Ferenčak, M. Gavranić, S. Babić, I. Mikac, M. Ahel, Comparison of four extraction methods 
for the determination of veterinary pharmaceuticals in sediment, Chromatographia 79 (2016) 209-223.

38. M. Kovačić, D. Juretić Perišić, M. Biošić, H. Kušić, S. Babić, A. Lončarić Božić, UV photolysis of diclofenac in water: kinetics, degradation pathway and environmental aspects, Environ. Sci. Pollut. Res. Int. 23 (2016) 14908-14917.

39. M. Runje, S. Babić, E. Meštrović, I. Nekola, Ž. Dujmić-Vučinić, N. Vojčić, Forced degradation of nepafenac: development and validation of stability indicating UHPLC method, J. Pharm. Biomed. Anal. 123 (2016) 42-52.

40. I. Tomaz, L. Maslov, D. Stupić, D. Periner, D. Ašperger, J. Karoglan Kontić, Recovery of Flavonoids from Grape Skins by Enzyme-Assisted Extraction, Sep. Sci. Technol. 51 (2016) 255-268.

41. S. Salaeh, D. Juretić Perišić, M. Biošić, H. Kušić, S. Babić, U. Stangar Lavrenčić, D. D. Dionysiou, A. Lončarić Božić, Diclofenac removal by simulated solar assisted photocatalysis using $\mathrm{TiO}_{2}$-based zeolite catalyst; mechanisms, pathways and environmental aspects, Chem. Eng. J. 304 (2016) 289302.

42. I. Tomaz, L. Maslov, D. Stupić, D. Periner, D. Ašperger, J. Karoglan Kontić, Multi-response optimisation of ultrasound- assisted extraction for recovery of flavonoids from red grape skins using response surface methodology, Phytochem. Analysis 27 (2016) 13-22.

43. D. Juretić Perišić, V. Gilja, M. Novak Stankov, Z. Katančić, H. Kušić, U. Lavrenčić Štangar, D. D. Dionysiou, A. Lončarić Božić, Removal of diclofenac from water by zeolite- assisted advanced oxidation processes, J. Photochem. Photobiol. A Chem. 321 (2016) 238-247.

44. T. Tomić, M. Milčić, N. Uzorinac Nasipak, S. Babić, Determination of chloride and sulfate in bio- ethanol by ion chromatography, Indian J. Chem. Techn. 23 (2016) 65-70.

45. I. Tomaz, L. Maslov, D. Stupić, D. Periner, D. Ašperger, J. Karoglan Kontić, Solid-liquid extraction of phenolics from red grape skins, Acta Chim. Slov. 63 (2016) 287-297.

\section{5.:}

46. M. Zrnčić, S. Babić, D. Mutavdžić Pavlović, Determination of thermodynamic pKa values of pharmaceuticals from five different groups using capillary electrophoresis, J. Sep. Sci. 38 (2015) 1232-1239.

47. D. Mutavdžić Pavlović, K. Nikšić, S. Livazović, I. Brnardić, A. Anžlovar, Preparation and application of sulfaguanidine- imprinted polymer on solid-phase extraction of pharmaceuticals from water, Talanta 131 (2015) 99-107.

48. S. Babić, M. Zrnčić, D. Ljubas, L. Ćurković, I. Škorić, Photolytic and thin $\mathrm{TiO}_{2}$ film assisted photocatalytic degradation of sulfamethazine in aqueous solution, Environ. Sci. Pollut. Res. Int. 22 (2015) 11372-11386.

49. D. Dolar, K. Košutić, D. Ašperger, Influence of adsorption of pharmaceuticals onto RO/NF membranes on their removal from water, Water Air Soil Pollut. 224 (2013) 1377-1-137713.

50. M. Smidt, H. Kušić, D. Juretić, M. Novak Stankov, Š. Ukić, T. Bolanča, M. Rogošić, A. Lončarić Božić, Modeling of photooxidative degradation of aromatics in water: optimization study using response surface and structural-relationship approaches, Ind. Eng. Chem. Rec. 54 (2015) 5427-5441.

51. Š. Ukić, M. Novak, A. Krilić, N. Avdalović, Y. Liu, B. Buszewski, T. Bolanča, Development of Gradient Retention Model in Ion Chromatography. Part III: Fuzzy Logic QSRR Approach, Chromatographia 78 (2015) 889-898.
2014.:

52. T. Bolanča, Š. Ukić, I. Peternel, H. Kušić, A. Lončarić Božić, Artificial neural network models for advanced oxidation of organics in water matrix - Comparison of applied methodologies, Indian J. Chem. Techn. 21 (2014) 21-29.

53. D. Mutavdžić Pavlović, L. Ćurković, D. Blažek, J. Župan, The sorption of sulfamethazine on soil samples: Isotherms and error analysis, Sci. Total Environ. 497-498 (2014) 543-552.

54. Š. Ukić, V. Mandić, Z. Buić, T. Bolanča, B. Zelić, S. Kurajica, M. Novak, Sorption kinetics and structural investigations of acid and alkali pretreated bentonite used for ammonium and phosphate removal from petrochemical wastewater, Fresen. Environ. Bull. 23 (2014) 1260-1270.

55. D. Ašperger, V. Tišler, M. Zrnčić, D. Mutavdžić Pavlović, S. Babić, A. J. M. Horvat, M. Kaštelan-Macan, HPLC-DAD-FLD Determination of Veterinary Pharmaceuticals in Pharmaceutical Industry Wastewater with Precolumn Derivatization Using Fluorescamine, Chromatographia 77 (2014) 1059-1066.

56. M. Periša, S. Babić, Simultaneous determination of pharmaceuticals and some of their metabolites in wastewaters by high performance liquid chromatography-tandem mass spectrometry, J. Sep. Sci. 37 (2014) 1289-1296.

57. M. Zrnčić, M. Gros, S. Babić, M. Kaštelan-Macan, D. Barcelo, M. Petrović, Analysis of anthelmintics in surface water by ultra high performance liquid chromatography coupled to quadrupole linear ion trap tandem mass spectrometry, Chemosphere 99 (2014) 224-232.

58. T. Bolanča, Š. Ukić, M. Novak, M. Rogošić, Computer assisted method development in liquid chromatography, Croat. Chem. Acta 87 (2014) 111-122.

59. D. Ašperger, L. Ćurković, A. J. M. Horvat, M. Kaštelan-Macan, Optimization condition for thin-layer identification of bronzes after anodic sampling, JPC-J. Planar. Chromat. 27 (2014) 84-87.

60. Š. Ukić, M. Novak, A. Vlahović, N. Avdalović, Y. Liu, B. Buszewski, T. Bolanča, Development of Gradient Retention Model in Ion Chromatography. Part II: Artificial Intelligence QSRR Approach, Chromatographia 77 (2014) 997-1007.

61. L. Ćurković, T. Bolanča, M. Šiljeg, L. Foglar, The kinetic modelling of $\mathrm{Fe}^{3+}$ ion uptake by zeolite from water, Indian J. Chem. Techn. 21 (2014) 56-62.

62. Š. Ukić, M. Novak, P. Žuvela, N. Avdalović, Y. Liu, B. Buszewski, T. Bolanča, Development of Gradient Retention Model in Ion Chromatography - Part I: Conventional QSRR Approach, Chromatographia 77 (2014) 985-996.

\section{3.:}

63. M. Periša, S. Babić, I. Škorić, T. Frömel, T. P. Knepper, Photodegradation of sulfonamides and their N4-acetylated metabolites in water by simulated sunlight irradiation: Kinetics and identification of photoproducts, Environ. Sci. Pollut. Res. Int. 20 (2013) 8934-8946.

64. M. Novak, I. Mohler, M. Golob, Ž. Ujević Andrijić, N. Bolf, Continuous estimation of kerosene cold filter plugging point using soft sensors, Fuel Process. Technol. 113 (2013) 8-19.

65. S. Babić, M. Periša, I. Škorić, Photolytic degradation of norfloxacin, enrofloxacin and ciprofloxacin in various aqueous media, Chemosphere 91 (2013) 1635-1642.

66. D. Dolar, K. Košutić, D. Ašperger, S. Babić, Removal of glucocorticosteroids and anesthetics from water with RO/NF membrane, Chem. Biochem. Eng. Q. 27 (2013) 1-6.

67. D. Mutavdžić Pavlović, D. Ašperger, D. Tolić, S. Babić, De- 
velopment and optimization studies for determination of pharmaceuticals in water samples by SPE and HPLC with diode-array detection, J. Sep. Sci. 36 (2013) 3042-3049.

68. Š. Ukić, P. Dimić, M. Šiljeg, M. Ujević Bošnjak, J. Šipušić, T. Bolanča, Manganese waste mud immobilization in cement - natural zeolite - lime blend: Process optimization using artificial neural networks and multi-criteria functions, Materialwiss. Werkst. 44 (2013) 273-281.

69. E. Dražević, K. Košutić, V. Dananić, D. Mutavdžić Pavlović, Coating Layer Effect on Performance of Thin Film Nanofiltration Membrane in Removal of Organic Solutes, Sep. Purif. Technol. 118 (2013) 530-539.

70. A. Švarc, Š. Ukić, S. Radojević Lacković, B. Đuričić, M. Novak Stankov, T. Bolanča, Influence of Ultrasonic and Microwave Irradiation on Cation Exchange Properties of Clay Material, Chem. Biochem. Eng. Q. 27 (2013) 29-35.

71. Š. Ukić, M. Rogošić, M. Novak, E. Šimović, V. Tišler, T. Bolanča, Optimization of IC Separation Based on Isocratic- to-Gradient Retention Modeling in Combination with Sequential Searching or Evolutionary Algorithm, J. Anal. Methods Chem. (2090-8873) (2013) 549729-1-549729-11.

72. M. Nestić, S. Babić, D. Mutavdžić Pavlović, D. Sutlović, Molecularly imprinted solid phase extraction for simultaneous determination of $\Delta 9$ - tetrahydrocannabinol and its main metabolites by gas chromatography-mass spectrometry in urine samples, Forensic Sci. Int. 231 (2013) 317-324.

73. D. Dolar, K. Košutić, M. Periša, S. Babić, Photolysis of enrofloxacin and removal of its photodegradation products from water by reverse osmosis and nanofiltration membranes, Sep. Purif. Technol. 115 (2013) 1-8.

74. M. Grdiša, S. Babić, M. Periša, K. Carović-Stanko, I. Kolak, Z. Liber, M. Jug-Dujaković, Z. Šatović, Chemical diversity of the natural populations of Dalmatian pyrethrum (Tanacetum cinerariifolium /Trevir. /Sch. Bip.) in Croatia, Chem. Biodivers. 10 (2013) 460-472.

75. M. Ivešić, S. Babić, A. Krivohlavek, Z. Šmit, Determination of cyanuric acid in whey powder using HILIC-MS/MS, Anal. Methods 5 (2013) 5188-5194.

76. G. Peček, D. Mutavdžić Pavlović, S. Babić, Development and validation of a SPE-GC-MS method for the determination of pesticide in surface water, Int. J. Environ. Anal. Chem. 93 (2013) 1311-1328.

77. D. Dolar, M. Periša, K. Košutić, S. Babić, NF/RO removal of enrofloxacin and its photodegradation products from water, Desalin. Water Treat. 51 (2013) 469-475.

\section{2.:}

78. D. Mutavdžić Pavlović, T. Pinušić, M. Periša, S. Babić, Optimization of matrix solid-phase dispersion for liquid chromatography tandem mass spectrometry analysis of 12 pharmaceuticals in sediments, J. Chromatogr. A 1258 (2012) 1-15.

79. S. Babić, M. Grdiša, M. Periša, D. Ašperger, Z. Šatović, M. Kaštelan-Macan, Ultrasound-assisted extraction of pyrethrins from pyrethrum flowers, Agrochimica (Pisa) 56 (2012) 193206.

80. T. Bolanča, S. Marinović, Š. Ukić, A. Jukić, V. Rukavina, Development of artificial neural network model for diesel fuel properties prediction using vibrational spectroscopy, Acta Chim. Slov. 59 (2012) 249-257.

81. T. Bolanča, J. Šipušić, Š. Ukić, M. Šiljeg, M. Ujević Bošnjak, Optimization of arsenic sludge immobilization process in cement - natural zeolite - lime blends using artificial neural networks and multi objective criteria functions, Fresen. Environ. Bull. 21 (2012) 76-83.
82. Š. Cerjan Stefanović, T. Bolanča, M. Luša, Š. Ukić, M. Rogošić, Multi-criteria decision making development of ion chromatographic method for determination of inorganic anions in oilfield waters based on artificial neural networks retention model, Anal. Chim. Acta 716 (2012) 145-154.

83. D. Dolar, A. Vuković, D. Ašperger, K. Košutić, Efficiency of $\mathrm{RO} / \mathrm{NF}$ membranes at the removal of veterinary antibiotics, Water Sci. Technol. 65 (2012) 317-323.

84. M. Trkmić, L. Ćurković, D. Ašperger, Chemical analysis of solid residue from liquid and solid fuel combustion: Method development and validation, Materialwiss. Werkst. 43 (2012) 503-510.

85. S. Marinović, T. Bolanča, Š. Ukić, V. Rukavina, A. Jukić, Prediction of diesel fuel cold properties using artificial neural networks, Chem. Tech. Fuels Oil 48 (2012) 67-74.

86. T. Tomić, N. Uzorinac Nasipak, S. Babić, Estimating measurement uncertainty in high- performance liquid chromatography methods, Accredit. Qual. Assur. 17 (2012) 291-300.

87. A. J. M. Horvat, M. Petrović, S. Babić, D. Mutavdžić Pavlović, D. Ašperger, S. Pelko, A. Dunja Mance, M. Kaštelan-Macan, Analysis, occurrence and fate of anthelmintics and their transformation products in the environment, Trend. Anal. Chem. 31 (2012) 61-84.

88. D. Dolar, T. Ignjatić Zokić, D. Ašperger, K. Košutić, D. Mutavdžić Pavlović, RO/NF membrane treatment of veterinary pharmaceutical wastewater: comparison of results obtained on a laboratory and pilot scale, Environ. Sci. Pollut. Res. Int. 19 (2012) 1033-1042.

\section{1.:}

89. Š. Ukić, T. Bolanča, M. Rogošić, Novel criteria for fast searching for optimal method in gradient ion chromatography: an integrated approach, J. Sep. Sci. 34 (2011) 780-788

90. V. Glavnik, B. Simonovska, I. Vovk, D. Mutavdžić Pavlović, D. Ašperger, S. Babić, Quantification of (-)-Epicatechin and Procyanidin B2 in Chocolates, JPC-J. Planar. Chromat. 24 (2011) 482-486.

91. T. Bolanča, Š. Ukić, A. Marinović Ruždjak, Development of an ion chromatographic method for determination of inorganic anions in surface water by using computer assisted gradient optimization methodology, Acta Chim. Slov. 58 (2011) 120-126.

92. D. Dolar, A. Vuković, D. Ašperger, K. Košutić, Effect of water matrices on removal of veterinary pharmaceuticals by nanofiltration and reverse osmosis membranes, J. Environ. Sci.-China 23 (2011) 1299-1307.

93. T. Bolanča, Š. Ukić, A. Marinović Ruždjak, Computer-assisted Development of ad hoc Methodology for Monitoring of Inorganic Cations in Surface Water Using Gradient Elution Ion Chromatography, Croat. Chem. Acta 84 (2011) 487-492.

94. M. Buljac, D. Bogner, ̌̌. Cerjan Stefanović, T. Bolanča, K. Margeta, $\mathrm{Cr}$ and $\mathrm{Zn}$ distribution in sediment from the semi-enclosed Kaštela Bay, the Adriatic Sea (Croatia), Fresen. Environ. Bull. 20 (2011) 853-860.

95. D. Doležal, T. Bolanča, Š. Cerjan Stefanović, Development of UV/VIS spectrometric methodology for corrosion inhibitor residuals monitoring in oilfield brine, Materialwiss. Werkst. 42 (2011) 229-233.

96. H. Kušić, I. Peternel, Š. Ukić, N. Koprivanac, T. Bolanča, S. Papić, A. Lončarić Božić, Modeling of iron activated persulfate oxidation treating reactive azo dye in water matrix, Chem. Eng. J. 172 (2011) 109-121. 


\section{0.:}

97. S. Babić, D. Mutavdžić Pavlović, D. Ašperger, M. Periša, M. Zrnčić, A. J. M. Horvat, M. Kaštelan-Macan, Determination of multi-class pharmaceuticals in wastewater by liquid chromatography-tandem mass spectrometry (LC-MS-MS), Anal. Bioanal. Chem. 398 (2010) 1185-1194.

98. T. Bolanča, Š. Cerjan Stefanović, M. Luša, Š. Ukić, M. Rogošić, Application of different artificial neural networks retention models for multi-criteria decision-making optimization in gradient ion chromatography, Sep. Sci. Technol. 45 (2010) 236-243.

99. D. Mutavdžić Pavlović, S. Babić, D. Dolar, D. Ašperger, K. Košutić, A. J. M. Horvat, M. Kaštelan-Macan, Development and optimization of the SPE procedure for determination of pharmaceuticals in water samples by HPLC-diode array detection, J. Sep. Sci. 33 (2010) 258-267.

100.T. Bolanča, Š. Ukić, M. Rogošić, Prediction of nonlinear gradient signal in ion chromatography based on "experiment-free" methodology, J. Liq. Chromatogr. R. T. 33 (2010) 1831-1841.

\section{9.:}

101.D. Ašperger, S. Babić, D. Mutavdžić Pavlović, D. Dolar, K. Košutić, A. J. M. Horvat, M. Kaštelan-Macan, SPE-HPLC/ DAD Determination of Trimethoprim, Oxytetracycline and Enrofloxacin in Water Samples, Int. J. Environ. Anal. Chem. 89 (2009) 809-819.

102.T. Bolanča, Š. Cerjan Stefanović, Š. Ukić, M. Luša, M. Rogošić, Prediction of the chromatographic signal in gradient elution ion chromatography, J. Sep. Sci. 32 (2009) 2877-2884.

103.T. Tomić, S. Babić, N. Uzorinac Nasipak, M. Fabulić Ruszkowski, L. Škrobonja, M. Kaštelan-Macan, Determination of alkenes in cracking products by normal-phase high-performance liquid chromatography - diode array detection, J. Chromatogr. A 1216 (2009) 3819-3824.

104.T. Bolanča, Š. Cerjan Stefanović, Š. Ukić, M. Rogošić, Development of Temperature Dependent Retention Models in Ion Chromatography by the Cascade Forward and Back Propagation Artificial Neural Networks, J. Liq. Chromatogr. R. T. 32 (2009) 2765-2778.

105. T. Bolanča, Š. Cerjan Stefanović, Š. Ukić, M. Luša, M. Rogošić, From Isocratic Data to a Gradient Elution Retention Model in IC: An Artificial Neural Network Approach, Chromatographia 70 (2009) 15-20.

106.D. Dolar, K. Košutić, D. Mutavdžić-Pavlović, B. Kunst, Removal of emerging contaminants of industrial origin by NF/ RO: a pilot scale study, Desalin. Water Treat.: Sci. Eng. 6 (2009) 197-203.

107.T. Bolanča, Š. Cerjan Stefanović, Š. Ukić, M. Rogošić, M. Luša, Application of a Gradient Retention Model Developed by Using Isocratic Data for the Prediction of Retention, Resolution, and Peak Asymmetry in Ion Chromatography, J. Liq. Chromatogr. R. T. 32 (2009) 1373-1391.

\section{Primjena kromatografskih tehnika na Zavodu za analitičku kemiju u znanstvenim projektima}

Članovi Zavoda kontinuirano se bave razvojem, optimizacijom i primjenom različitih analitičkih metoda određivanja kemijskih spojeva te proučavanjem principa na koji- ma se pojedine analitičke tehnike temelje. $U$ posljednjem desetljeću područje njihova znanstveno-istraživačkog djelovanja najvećim dijelom odnosi se na analizu okoliša, s posebnim naglaskom na prisutnost vrlo aktualne tematike novih onečišćivala u vodama, ponajviše humanih i veterinarskih farmaceutika, hormona te pesticida (tablica 1). ${ }^{9,10}$

MZO-ov projekt Procesi ionske izmjene u sustavu kvalitete industrijskih voda fokusiran je na činjenicu da je voda presudan resurs za život na zemlji, ali nažalost nipošto nije i nepresušan resurs. Stoga je potrebno kvalitetno gospodariti vodom, odnosno vodu kao sirovinu optimalno iskoristiti a potencijalna zagađivala ukloniti ili reducirati prikladnim tehnikama. Kao jedna od vrlo zahvalnih tehnika nametnula se ionska izmjena, ponajprije uzimajući u obzir činjenicu da u regiji postoje relativno velike količine jeftine sirovine: prirodnog ionskog izmjenjivača zeolita. Primjena ionskih izmjenjivača omogućila bi visoku efikasnost uklanjanja nečistoća u industrijskim vodama, čime bi se one mogle upotrebljavati višekratno. Koncentrirane pak otopine, dobivene regeneracijom ionskih izmjenjivača, mogle bi se kao sirovina vraćati u proizvodni proces.

U okviru projekata REPHAD i Razvoj naprednih analitičkih metoda za određivanje farmaceutika u okolišu razvijene su i optimirane kromatografske metode za istodobno određivanje niza farmaceutika iz različitih strukturnih skupina (HPLC-DAD, HPLC-FLD i HPLC-MS) kao i postupci pripreme uzoraka vode (ekstrakcija čvrstom fazom (SPE), ekstrakcija visokoselektivnim polimernim sorbensom s otiskom molekule (MIP) i mikroekstrakcija miješalom) te uzoraka sedimenta (ultrazvučna (USE) i mikrovalna ekstrakcija (MASE) te ekstrakcije raspršenjem matice uzorka kroz čvrstu fazu (MSPD)). Razvijene metode omogućile su izolaciju analita iz kompleksnih uzoraka okoliša, poboljšanje analitičkih osobina metoda te smanjenje zagađenja okoliša zbog uporabe daleko manjeg volumena štetnih otapala. Razvoj metoda tekućinske kromatografije visoke djelotvornosti vezane sa spregnutom spektrometrijom masa (HPLCMS/MS) omogućio je praćenje nižih koncentracija farmaceutika i preliminarnu identifikaciju razgradnih produkata.

Ostvareni rezultati omogućili su proširivanje istraživanja na proučavanje ponašanja farmaceutika u okolišu i učinkovitosti njihova uklanjanja naprednim postupcima obrade otpadnih voda. U takvim istraživanjima temelj je pouzdana analitička metoda. Stoga se velika pažnja posvećuje razvoju i optimizaciji mjernog sustava, imajući na umu da svaki korak analitičkog procesa pridonosi nesigurnosti konačnog rezultata; razvijene metode potrebno je validirati kako bi se nepobitno utvrdila njihova primjenjivosti za analizu niskih koncentracija organskih spojeva u kompleksnim uzorcima iz okoliša te potvrdila pouzdanost dobivenih rezultata.

U okviru projekta PharmaFate istraživanja su usmjerena na proučavanje potencijalnih putova eliminacije farmaceutika u okolišu te učinkovitosti naprednih oksidacijskih procesa u uklanjanju farmaceutika iz otpadnih voda. U okviru istraživanja vezanih uz sudbinu farmaceutika u okolišu istražena je hidrolitička i fotolitička razgradnja izabranih farmaceutika u uvjetima relevantnim za okoliš te njihova sorpcija na tlo i riječni sediment. Razgradnja farmaceutika tijekom postupaka obrade voda i u uvjetima relevantnim za okoliš praćena je primjenom naprednih analitičkih me- 
toda (HPLC-MS/MS). Ispitan je utjecaj tvari uobičajeno prisutnih u vodenom okolišu na razgradnju farmaceutika, određena je kinetika razgradnje, identificirani su razgradni produkti te predloženi mehanizmi i putovi razgradnje. Za pravilnu procjenu rizika za ekosustave izložene spojevima poput farmaceutika takva istraživanja su nužna. S obzirom da naprednom oksidacijom farmaceutika tijekom obrade voda (AOP), ali i njihovom razgradnjom uslijed procesa koji se odvijaju u okolišu (hidroliza i fotoliza) nastaju novi spojevi koji mogu imati bitno drukčija fizikalna, kemijska i toksična svojstva, bitno je procijeniti učinak razgradnje na okoliš. Stoga se znanstvena istraživanja proširuju na procjenu akutne toksičnosti (Vibrio fischeri) samih farmaceutika i praćenje toksičnosti njihove smjese s produktima koji nastaju tijekom razgradnje. U okviru bilateralnog projekta Determination of ecotoxicity and physico-chemical proper- ties of pharmaceuticals ta istraživanja proširuju se na procjenu citotoksičnosti i genotoksičnosti.

Projekt Modeliranje okolišnih aspekata napredne obrade voda za razgradnju prioritetnih onečišćivala bavi se tzv. prioritetnim onečišćivalima, tj. tvarima koje predstavljaju značajan rizik vodenom okolišu; u konkretnom slučaju pesticidima, farmaceuticima i hormonima. Konvencionalni pristupi obradi voda uglavnom se oslanjaju na fizikalne i biološke procese te su kao takvi uglavnom nedovoljno efikasni za uklanjanje prioritetnih onečišćivala. S ciljem pronalaska održive tehnologije za uklanjanje tih tvari iz okoliša odnosno ponajprije iz voda u sklopu projekta provedena su istraživanja primjenom različitih tretmana uklanjanja onečišćivala iz voda naprednim oksidacijskim procesima: $\mathrm{UV} / \mathrm{H}_{2} \mathrm{O}_{2}, \mathrm{UV} / \mathrm{S}_{2} \mathrm{O}_{8}{ }^{2-}$ oksidacija te oksidacija feratom. Ispituje se povezanost strukturnih karakteristika onečišćivala,
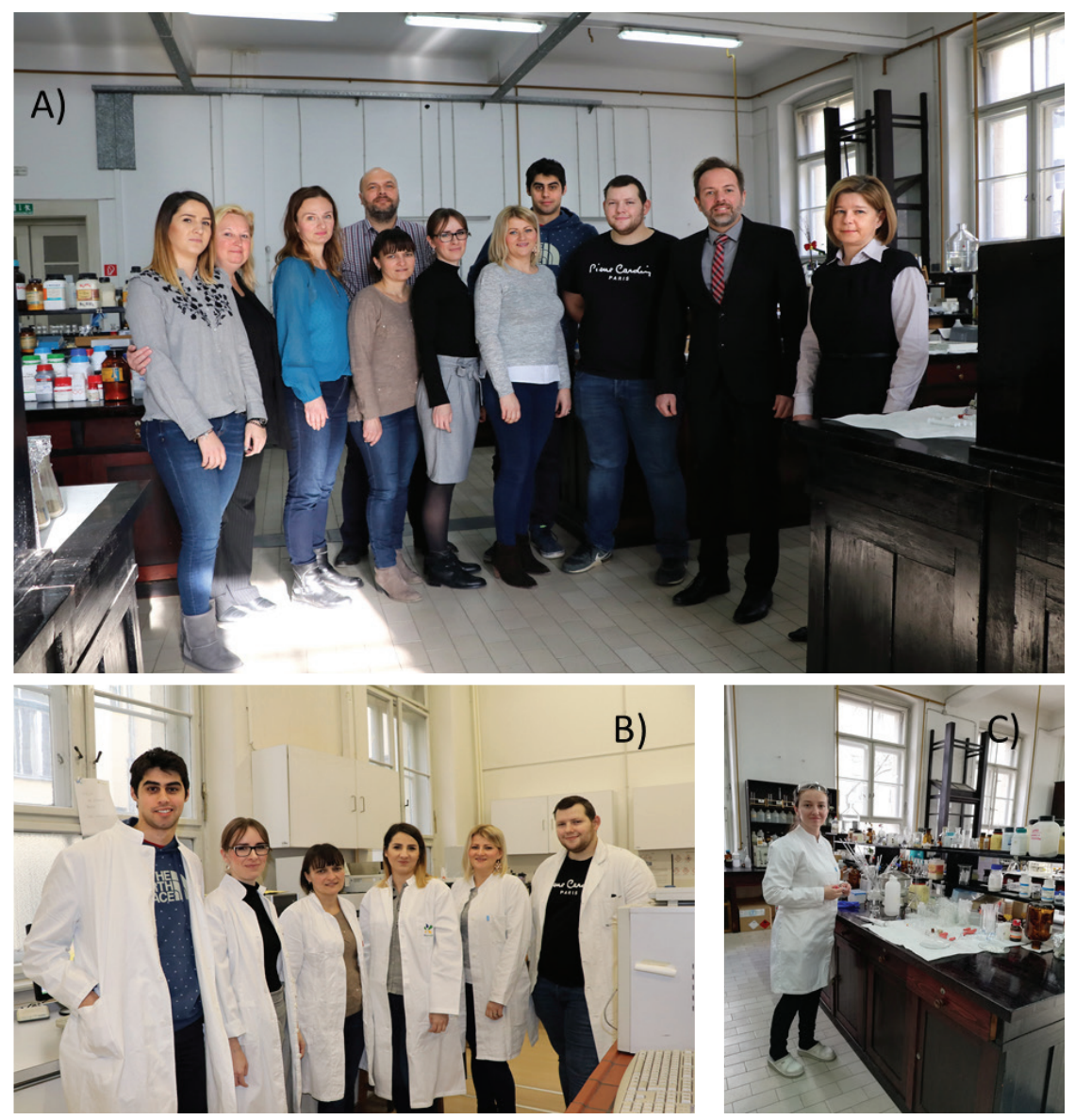

Slika 2 - A) Članovi Zavoda za analitičku kemiju u stogodišnjem Laboratoriju za mokru kemiju (s lijeva na desno): Kristina Tolić, Danijela Ašperger, Dragana Mutavdžić Pavlović, Šime Ukić, Slavica Kos, Martina Biošić, Tanja Ivančić, Dario Dabić, Matija Cvetnić, Tomislav Bolanča i Sandra Babić; B) mlade snage Zavoda s tehničkim suradnicama u Laboratoriju za kemijsku analizu okoliša; C) Mirjana Novak Stankov priprema uzorke za kromatografsku analizu.

Fig. 2 - A) Members of the Department of Analytical Chemistry in the centennial Laboratory for Wet Chemistry (from left to right): Kristina Tolić, Danijela Ašperger, Dragana Mutavdžić Pavlović, Šime Ukić, Slavica Kos, Martina Biošić, Tanja Ivančić, Dario Dabić, Matija Cvetnić, Tomislav Bolanča, and Sandra Babić; B) young forces of the Department with technical associates in Laboratory for Chemical Analysis of the Environment; C) Mirjana Novak Stankov prepares the samples for chromatographic analysis. 
D. AŠPERGER at al.: Kromatografska analiza u sustavu kvalitete analitičkoga procesa u Zavodu ..., Kem. Ind. 68 (9-10) (2019) 535-546 || 543

Tablica 1 - Popis domaćih i međunarodnih projekata na kojima sudjeluju djelatnici Zavoda za analitičku kemiju u razdoblju od 2009. do 2019.9,10

Table 1 - List of national and international projects attended by the staff of the Department of Analytical Chemistry from 2009 to 2019. ${ }^{9,10}$

Domaći projekti

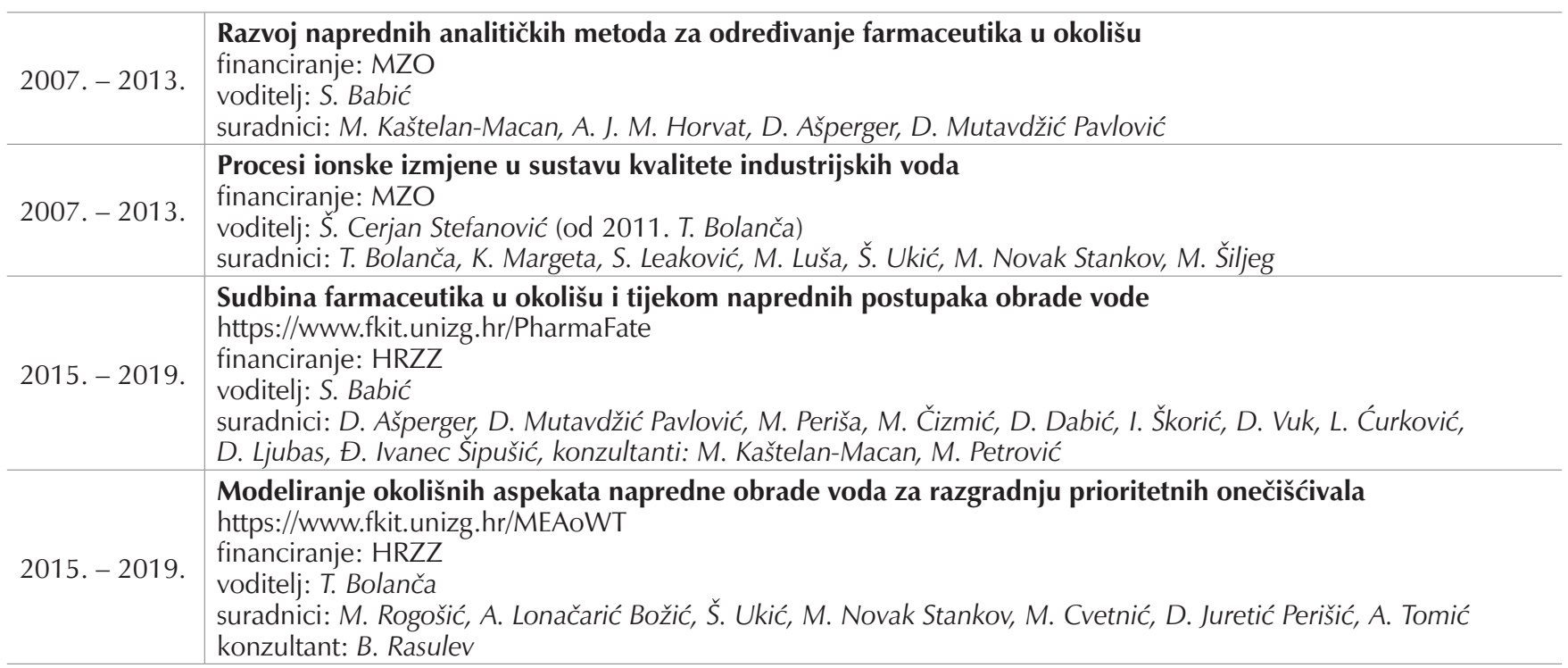

\section{Međunarodni projekti}

2007. - 2010. Reduction of environmental risks posed by pharmaceuticals and their degradation products in process wastewaters, through RO/NF membrane treatment (REPHAD)

https://pierre.fkit.hr/ukf/

financiranje: Fond Jedinstvo uz pomoć znanja (UKF)

voditelji: M. Kaštelan-Macan i M. Petrović (Catalan Institute for Research and Advanced Studies, Girona, Španjolska)

suradnici: B. Kunst, A. J. M. Horvat, K. Košutić, S. Babić, D. Ašperger, D. Mutavdžić Pavlović,

D. Dolar, N. Kuntarić, S. Pelko, E. Dražević, A. D. Mance

2007. - 2012. Education in separation and identification of organic xenobiotics

in environmental samples and food product

financiranje: CEEPUS

voditelj: A. J. M. Horvat

suradnici: -

2011. - 2017. Determination of xenobiotics by using separation and hyphenated techniques

for environment, food and human health purposes

financiranje: CEEPUS

voditelj: T. Bolanča

suradnici: -

2012. - 2013. Determination of ecotoxicity and physico-chemical properties of pharmaceuticals

financiranje: $M Z O$, bilateralni

voditelj: D. Ašperger

suradnici: S. Babić, D. Mutavdžić Pavlović, M. Čizmić, M. Biošić

2019. - 2023. Joint PhD Laboratory for New Materials and Inventive Water Treatment Technologies.

Harnessing resources effectively through innovation (NOWELTIES)

https://nowelties.eu/

financiranje: H2020, MARIE SKŁODOWSKA-CURIE ACTIONS, Innovative Training Networks (ITN)

voditelj: M. Petrović (group leader for FKIT: S. Babić)

suradnici: D. Mutavdžić Pavlović, H. Kušić

\section{Sudjelovanje na projektima}

2007. - 2012. financiranje: HRZZ

Utjecaj prehrambenih vlakana na bioraspoloživost polifenola

istraživanjem adsorpcije $\mathrm{i}$ simuliranih probavnih procesa, in vitro

voditelj: L. Jakobek Barron (Sveučilište J. J. Strossmayera, Osijek)

suradnici sa ZAK-a: $\breve{S}$. Ukić 
Tablica 1 - (nastavak)

Table 1 - (continued)

Sudjelovanje na projektima (nastavak)

\begin{tabular}{|c|c|}
\hline 2012. - 2016. & $\begin{array}{l}\text { COST ACTION ES1202: Conceiving Wastewater Treatment in } 2020 \text { - Energetic, environmental and } \\
\text { economic challenges (Water 2020) } \\
\text { financiranje: EU } \\
\text { voditelj: J. M. Lema (University of Santiago de Compostela, Spain) } \\
\text { suradnici sa ZAK-a: D. Mutavdžić Pavlović }\end{array}$ \\
\hline 2016. - 2017. & $\begin{array}{l}\text { Synthesis and photocatalytic properties of nanostructured materials based on } \mathrm{TiO}_{2} \\
\text { financiranje: MZO, bilateralni hrvatsko - srpski projekt } \\
\text { voditelj: L. Ćurković (SuZ, Fakultet strojarstva i brodogradnje) } \\
\text { suradnici sa ZAK-a: S. Babić, M. Čizmić }\end{array}$ \\
\hline $2017 .-2019$. & $\begin{array}{l}\text { Izravna oporaba komunalne otpadne vode za navodnjavanje membranskim tehnologijama } \\
\text { http://www.hrzz.hr/default.aspx?id=78\&pid=4650\&rok=2016-06 } \\
\text { financiranje: HRZZ } \\
\text { voditelj: D. Dolar (SuZ, FKIT, Zavod za fizikalnu kemiju) } \\
\text { suradnici sa ZAK-a: D. Ašperger }\end{array}$ \\
\hline $2017 .-2021$. & $\begin{array}{l}\text { Genetska osnova insekticidnog potencijala dalmatinskog buhača } \\
\text { (Tanacetum cinerariifolium /Trevir./ Sch. Bip.) } \\
\text { http://www.hrzz.hr/default.aspx?id=78\&pid=4234\&rok=2016-06 } \\
\text { financiranje: HRZZ } \\
\text { voditelj: M. Grdiša (SuZ, Agronomski fakultet) } \\
\text { suradnici sa ZAK-a: M. Biošić }\end{array}$ \\
\hline 2017. - 2021 & $\begin{array}{l}\text { COST ACTION CA16215: } \\
\text { European network for the promotion of portable, affordable and simple analytical platforms } \\
\text { financiranje: EU } \\
\text { voditelj: G. Erny (University of Porto, Portugal) } \\
\text { suradnici sa ZAK-a: D. Mutavdžić Pavlović }\end{array}$ \\
\hline 2018. - 2020. & $\begin{array}{l}\text { Istraživanje procesa koji se odvijaju u vodoopskrbnim sustavima } \\
\text { financiranje: HRZZ } \\
\text { voditelj: M. Ujević Bošnjak (HZJZ) } \\
\text { suradnici sa ZAK-a: M. Novak Stankov }\end{array}$ \\
\hline 2018. - 2022. & $\begin{array}{l}\text { Istraživanje antioksidativnog djelovanja benzazolskog skeleta u dizajnu novih antitumorskih agensa } \\
\text { https://www.fkit.unizg.hr/AntioxPot } \\
\text { financiranje: HRZZ } \\
\text { voditelj: M. Hranjec (SuZ, FKIT, Zavod za organsku kemiju) } \\
\text { suradnici sa ZAK-a: D. Mutavdžić Pavlović, K. Tolić }\end{array}$ \\
\hline 2019. - 2020. & $\begin{array}{l}\text { Nanostructured } \mathrm{Au}-\mathrm{TiO}_{2} \text { films on porous } \mathrm{Al}_{2} \mathrm{O}_{3} \text { ceramics: } \\
\text { synthesis and application in advanced oxidation processes } \\
\text { financiranje: bilateralni hrvatsko-srpski projekt } \\
\text { voditeljica: L. Ćurković (SuZ, Fakultet strojarstva i brodogradnje) } \\
\text { suradnici sa ZAK-a: S. Babić, M. Čizmić }\end{array}$ \\
\hline 2019. - 2023. & $\begin{array}{l}\text { Višestruki stresori u vodenom okolišu: razumijevanje svojstava stresora i receptora } \\
\text { http://www.hrzz.hr/default.aspx?id=78\&pid=7372\&rok=2018-01 } \\
\text { financiranje: HRZZ } \\
\text { voditelj: M. Rožman (Institut Ruđer Bošković) } \\
\text { suradnici sa ZAK-a: S. Babić, M. Čizmić }\end{array}$ \\
\hline
\end{tabular}

mehanizama i kinetike njihove razgradnje te parametara primjenjivanih procesa oksidacije s ekotoksikološkim pokazateljima vode.

Kvaliteta znanstvenog rada članova Zavoda prepoznata je u domaćoj i međunarodnoj znanstvenoj zajednici, pa tako analitičari sudjeluju u brojnim drugim domaćim i međunarodnim projektima dajući svoj znanstveni doprinos primjenom razvijenih analitičkih metoda u praćenju učinkovitosti uklanjanja farmaceutika u membranskim postupcima obrade voda (Izravna oporaba komunalne otpadne vode za navodnjavanje membranskim tehnologijama) i učinkovitosti novih fotokatalitičkih materijala (Synthesis and pho- tocatalytic properties of nanostructured materials based on $\mathrm{TiO}_{2}$ i Nanostructured $\mathrm{Au}-\mathrm{TiO}_{2}$ films on porous $\mathrm{Al}_{2} \mathrm{O}_{3}$ ceramics: synthesis and application in advanced oxidation processes), kroz proučavanje međuodnosa UV filtara - farmaceutski aktivnih tvari tijekom fotolitičkih procesa (Višestruki stresori u vodenom okolišu: razumijevanje svojstava stresora i receptora) te razvoj analitičkih metoda za određivanje piretrina u dalmatinskom buhaču (Genetska osnova insekticidnog potencijala dalmatinskog buhača (Tanacetum cinerariifolium /Trevir./ Sch. Bip.)) ili pak primjeni kemometrije za rješavanje različitih zdravstvenih (Utjecaj prehrambenih vlakana na bioraspoloživost polifenola istraživanjem adsorpcije i simuliranih probavnih procesa, in vitro) i zdrav- 
stveno-tehnoloških problema (Istraživanje procesa koji se odvijaju u vodoopskrbnim sustavima). Znanstvena kvaliteta istraživanja članova Zavoda dodatno je potvrđena njihovim uključivanjem u projekt NOWELTIES, EU programa Obzor 2020, u okviru kojega će nastaviti istraživanja na gore spomenutim problematikama.

\section{Zaključak}

S obzirom na navedeno, može se zaključiti da su kromatografske tehnike tek na putu prema svojem vrhuncu te da se na tom području još mnogo toga može otkrivati. Kromatografija svojim interdisciplinarnim pristupom pokriva niz područja istraživanja, što su naši prethodnici dokazivali tijekom stogodišnje povijesti Zavoda, ali i novi naraštaji znanstvenika i nastavnika svojim znanstveno-istraživačkim i nastavnim djelovanjem. Zavod za analitičku kemiju od svojeg je postanka pa do danas njegovao tradiciju prateći suvremene trendove na području analitičke kemije s naglaskom na kromatografske tehnike i stvorio svojevrsnu prepoznatljivost, što dokazuje i održavanje skorašnje 20. Međunarodne škole kromatografije, koja okuplja iz godine u godine sve više sudionika iz cijele Europe, ali i šire.

I na kraju, budući da 18. prosinca obilježavamo Dan Zavoda za analitičku kemiju, pri čemu i sami slavimo stoti rođendan, želimo pokazati da smo nastavili tragom naših profesora te da i nadalje pokazujemo zamjetnu nastavnu, znanstvenu, stručnu i društvenu djelatnost što dokazuju različite suradnje s bivšim studentima, dobivene Rektorove i Dekanove nagrade za najbolje znanstvene radove, nagrada Franjo Hanaman profesorici Sandri Babić za promicanje imena Fakulteta, nagrada za zapažen znanstveni rad od Hrvatske udruge sveučilišnih nastavnika doktorici Mirti Čizmić, osnivanje prve spin off tvrtke Comprenhesive Water Technologies, čiji je direktor današnji dekan prof. dr. sc. To- mislav Bolanča, dobivanje priznanja i nagrada na području inovacija (Danijela Ašperger, Šime Ukić, Tomislav Bolanča, Mirjana Novak Stankov, Matija Cvetnić). Sve to doprinosi prepoznatljivosti Zavoda za analitičku kemiju (slika 2) s nadom da ćemo na tome tragu i ostati na ponos svih naših profesora od kojih smo učili.

\section{Literatura \\ References}

1. Kromatografsko nazivlje, ur. Š. Cerjan-Stefanović, V. Drevenkar, B. Jurišić, M. Medić-Šarić, M. Petrović, N. Šegudović, V. Švob, S. Turina, nakladnik HINUS d. o. o. i Sekcija za kromatografiju HDKI, Zagreb, 1999.

2. M. Kaštelan-Macan, Kemijska analiza u sustavu kvalitete, Školska knjiga, Zagreb, 2003.

3. Plošna kromatografija, ur. M. Kaštelan-Macan, M. Medić-̌̌arić, S. Turina, nakladnik Farmaceutsko-biokemijski fakultet Sveučilišta u Zagrebu, Zagreb, 2006.

4. Analitika okoliša, ur. M. Kaštelan-Macan, M. Petrović, nakladnik HINUS i Fakultet kemijskog inženjerstva i tehnologije Sveučilišta u Zagrebu, Zagreb, 2013.

5. M. Kaštelan-Macan, Enciklopedijski rječnik analitičkog nazivlja, nakladnik Fakultet kemijskog inženjerstva i tehnologije Sveučilišta u Zagrebu i Mentor d. o. o., Zagreb, 2014.

6. Monografija "Zavod za analitičku kemiju 1919. - 1999.", ur. M. Kaštelan-Macan, A. J. M. Horvat, nakladnik Fakultet kemijskog inženjerstva i tehnologije Sveučilišta u Zagrebu, Zagreb, 1999.

7. Monografija "Nova mladost devedestogodišnjaka - Zavod za analitičku kemiju 1999.-2009.", ur. S. Babić, M. Kaštelan-Macan, nakladnik Fakultet kemijskog inženjerstva i tehnologije Sveučilišta u Zagrebu, Zagreb, 2009.

8. Popis radova: CROSBI https://www.bib.irb.hr/ (datum preuzimanja 11. 9. 2019.).

9. Ključna riječ: Projekti https://www.fkit.unizg.hr/znanost/nacionalni_projekti (11. 9. 2019.).

10. Ključna riječ: Projekti https://www.fkit.unizg.hr/znanost/medunarodni_projekti (11.9. 2019.). 


\section{SUMMARY}

\section{Chromatographic Analysis in the Quality System of Analytical Process in the Department of Analytical Chemistry of the Faculty of Chemical Engineering and Technology

\author{
Danijela Ašperger, Sandra Babić, Tomislav Bolanča,
} Dragana Mutavdžić Pavlović, and Šime Ukić}

Without analytical chemistry, it is impossible to imagine the progress of many areas of human activity. The aforementioned importance of this chemistry branch is one of the main reasons for the successful survival and continued development of the Department of analytical chemistry within a technical faculty, such as is the present-day Faculty of Chemical Engineering and Technology (FCET) University of Zagreb. The dynamics of the development of analytical chemistry was a constant encouragement to the teachers of the Department to adapt to world trends, and systematically improve the curriculum and research work.

The beginning of the teaching, the scientific, as well as the professional activities of the Department of Analytical Chemistry was based on classical methods of analysis. However, stimulated by the development of modern analytical equipment, the application of numerous chemical and physicochemical methods of analysis was intensified, of which the most common being chromatography. Namely, the end of the twentieth century accelerated the development of instrumental techniques, the introduction of computers, and the fact that analytical measurement data became the basis of decision-making in medicine, environmental protection, material development, and assuring the quality of processes and products gave rise to analytical chemistry, especially chromatography, which is an ideal technique for multicomponent trace analyte analysis.

\section{Keywords}

Chromatography, analytical chemistry, quality system, environment

Department of Analytical Chemistry

Faculty of Chemical Engineering and Technology

Review

University of Zagreb

Marulićev trg 19

10000 Zagreb, Croatia

Received September 20, 2019

Accepted September 26, 2019 